\title{
Narrative Inquiry and Historical Skills. A Study in Teacher Training ${ }^{1}$ Investigación narrativa y habilidades históricas. Un estudio sobre la formación de maestros
}

\author{
Cosme J. Gómez Carrasco (1) cjgomez@um.es \\ Jorge Sáiz (2) jorge.saiz@uv.es \\ (1) Universidad de Murcia \\ (2) Universidad de Valencia \\ (Received: September 8, 2014; accepted for publishing: May 17, 2016)
}

How to cite: Gómez, C. J., \& Sáiz, J. (2017). Narrative inquiry and historical skills. A study in teacher training. Revista Electrónica de Investigación Educativa, 19(4), 19-32. Retrieved from https://doi.org/10.24320/redie.2017.19.4.910

\begin{abstract}
This paper addresses narrative thinking and literacy levels in future primary school teachers in Spain. It uses the study of a historical synthesis of one of the main narratives in Spanish history: the Christian expansion through Muslim territories in the Iberian Peninsula in the Middle Ages. Accounts by 283 students of the degree in elementary school teaching at the universities of Valencia and Murcia were studied. The aim was to ascertain the students' discursive abilities with respect to their historical thinking skills. The results reveal poor narrative skills in future teachers and a very low level of historical literacy.
\end{abstract}

Keywords: Narrative inquiry, History education, Elementary school teacher training.

\section{Resumen}

Este trabajo aborda el pensamiento narrativo y los niveles de alfabetización histórica en futuros maestros de Primaria en España. Para el estudio se utilizó una síntesis histórica de una de las principales narrativas de la historia española: la expansión cristiana a través de los territorios musulmanes de la Península Ibérica en la Edad Media. Se estudiaron las narrativas de 283 alumnos del grado de Educación Primaria de Valencia y Murcia. El objetivo fue determinar las habilidades discursivas de los estudiantes con respecto a sus habilidades de pensamiento histórico. Los resultados revelan habilidades narrativas pobres en futuros maestros y un nivel muy bajo de alfabetización histórica.

Palabras clave: Investigación narrativa, Enseñanza de la historia, Educación primaria, Formación del profesorado.

\footnotetext{
${ }^{1}$ This paper is result of research project EDU2015-65621-C3-2-R "La evaluación de las competencias y el desarrollo de capacidades cognitivas sobre Historia en Educación Secundaria Obligatoria"; EDU2015-65621-C3-R "Competencias sociales para una ciudadanía democrática: análisis, desarrollo y evaluación"; EDU2014-51720-REDTRED14 "Red de investigación en enseñanza de las Ciencias Sociales" funded by Ministry of Economy and Competitiveness.
} 


\section{Introduction}

In the last two decades much work has been published on what history should be taught, the educational value of historical knowledge, and the importance of learning about history. We support a learning process based on abilities that allow students to interpret the past, and which go beyond factual or conceptual knowledge based on the memorization of dates, characters or facts. It is about an approach focused on history comprehension as a method. It consists of learning history as a form of research and learning to think and reflect on the past (Barca, 2000, 2011; Carretero \& López, 2009; Carretero \& Voss, 2004; Clark, 2011; Gómez, 2014; Gómez \& Miralles, 2015; Lévesque, 2008, 2011; Peck \& Seixas, 2008; Prats \& Santacana, 2011; Saiz, 2015; Sáiz \& López Facal, 2015; Schmidt \& Barca, 2009; Stearns, Seixas \& Wineburg, 2000; Van Sledright, 2011; Wineburg, 2001). These studies have distinguished between two types of historical content.

On the one hand, substantive or first-order content is related to concepts or principles such as dates and specific historical facts. On the other hand, studies distinguish the strategic content of second-order or historical meta-concepts. These are defined by the knowledge and use of different capacities or competences to give an answer to historical matters and gain a more complex understanding of the past: this is knowledge related to historical skills, such as searching for, selecting and processing historical sources, empathy or historical perspective (Van Sledright, 2014; Wineburg, 2001).

According to Seixas and Morton (2013), historical thinking can be defined as the creative process that historians go through to interpret sources from the past and generate historical narratives. To develop this process, six key concepts must be considered: historical significance; historical evidence; change and continuity; causes and consequences; historical perspective; and the ethical dimension of history. This proposal fits into the context of an ever greater interest, in the USA and Canada, in the definition of knowledge about history (Barton \& Levstik, 2004; Stearns, Seixas \& Wineburg, 2000; Van Sledright, 2011; Wineburg, 2001). In addition to that, from an empirical perspective, we wanted to place emphasis on the abilities of thinking, reading, writing and giving historical support, which are considered historical literacy (Monte-Sano, 2010; Wineburg, Martin \& Monte-Sano, 2013).

In Britain a great effort has also been made to analyze second-order concepts in student reasoning. In that regard it is important to mention the results of the project Concepts of History and Teaching Approaches (Lee \& Ashby, 2000; Lee, Ashby \& Dickinson, 2004; Lee 2005). The early stages of this project were based on an analysis of students' historical skills through the use of sources and historical empathy exercises, and more recently through different ways of setting out the fortuity of historical facts. On the other hand, the work by Chapman (2011) and the project Constructing History 11-19 (Cooper \& Chapman, 2009) have furthered this line of research through reasoning on the use of sources. A thematic line has also been applied in countries such as the Netherlands (Van Drie \& Van Boxtel, 2008).

These studies have agreed on the need to have teachers that question the cognitive learning model of history (VanSledright, 2014). Contrary to common belief, knowing history does not mean memorizing facts, concepts and dates. Understanding history implies other aspects related to complex thinking processes. This type of historical thinking is acquired through gradual participation in the practice of the history (Gómez, Ortuño \& Molina, 2014). History is a discipline that takes as its object the study of the past and is formed in a community of researchers that set out questions and approach the footsteps of the past through critical methods.

The perspective through which the past is treated depends on sociocultural and temporal factors that vary with the identity, beliefs and values of the researcher himself. History is a construction and it must be taught as such in the classroom. History teachers need to have a solid theoretical grounding in the formation of historical thinking and comprehension in students, the learning process of the discipline, and in identifying indicators of cognitive progression.

However, in recent years several authors have warned of the low value of a "skills versus conceptual content" debate (Cain and Chapman, 2014). As Lee (2011) indicates, historical knowledge implies 
reflection and critical judgment, and cannot be acquired simply through repetitive practice of unconnected skills lacking proper reasoning and knowledge of key historical processes and concepts. Students must have a clear understanding of the historical discipline and the key ideas that make knowledge of the past possible, including how historians explain the past and construct their historical narratives (Seixas and Morton, 2013). Students should be inclined to make the best possible arguments based on evidence, and notably historical evidence. But they also need to have coherent and substantive historical knowledge that allows them to use this evidence properly, at different scales, and with correct temporal understanding (Lee, 2011). However, teachers often find themselves up against a major sticking point: students' misconceptions about historical reasoning and interpretation. Lee (2001) and Lee and Shelmit (2004) have studied in depth the ideas and preconceptions of students in this respect, and the epistemological problems that result from them.

Students' historical reasoning and their narrative representation of the past are key aspects of recent studies on history teaching. Narration has begun to be valued as a teaching approach (Henríquez, 2004) and as an important subject of research (McEvan \& Egan, 1998). As stated by Carretero \& Van Alphen (2014), knowledge of history and the construction of narratives are closely related. The exclusion of narratives from history teaching impoverishes the focus of classes and deprives social events of their singularity. In addition, it should not be forgotten that the development of narratives can be a fitting way of explaining, and introducing children to, historical processes and concepts so they may begin to understand them.

Narrative thinking is a basic mental operation that provides meaning and enables organization of the past (Carretero \& Atorresi, 2008; Ricoeur, 1995; Rüsen, 2005 and 2010). If we ask students for a written synthesis, we discover not only what processes the students know, but also how they represent and organize them. As underlined by Barton and Levstik (2004), implicit in the narrative discourse are the use of the time dimension, the establishment of causal nexuses, and some means of granting historical importance and of connecting present and past from a moral perspective. Thus, using narratives with students allows one to reflect on history as a construction, because the narration is not simply an account of what happened but implies much more about the psychological perspective adopted by the narrator (Bage, 1999; Monte-Sano, 2010; Topolsky, 2004).

It is precisely the construction of narrations that enables us to value the internal processes of knowledge building. According to Bruner (1986; 1990), it enables us to discern both the level of substantive knowledge (enumeration of sure content about an event) and the level of awareness of second-order content (what we know about beliefs, motivations, emotions and willingness in past actions). At the same time, accounts provide information about progress in students' learning and their capacity to organize and understand the past. As McAdams (2006) states, the structure of the narration, its justification and causality, and the paradoxes reflected in narrative composition are a clear indicator of how mature a student's thinking is. As Bruner (1997, p. 168) puts it "We live most of our lives in a world constructed according to the rules and devices of narrative". Given these circumstances the analysis of narration in history teaching is gaining ever greater importance, not only in the research into the accounts constructed by students, but also in the analysis of how the main national narratives are chosen and their interconnection through formal and non-formal teaching (Carretero \& Bermúdez, 2012).

Skills related to narration, such as "narrative competence", are a way of representing or bestowing meaning on the past through three specific competencies that narration encompasses (content, formmeaning, and function): "temporal competency" (content), as knowledge of past phenomena or content; "interpreting competency" (form-meaning), as the capacity to find meaning in this content; and "orientation competency" (function), as the disposition to put the past to use in guiding the present and in moral values (Rüsen, 2010). Students' narrative examinations show how they express different historical meta-concepts. The influence of cultural studies and the linguistic turn have meant that increasing attention is being paid to the discursive analysis of students as narrators, and to the ways in which they express their ideas about the past (Barton, 2010). In this sense, great importance is attached to the "schematic narrative template" concept used by Wertsch (2002) as a cultural mediation tool generated and spread among a social group, and which is perfectly applicable to historical and national narratives (Carretero \& López, 2010; Carretero, López, Fernanda \& Rodríguez-Moneo, 2012). There is a 
powerful narrative mediation in knowledge and school historical memories on account of the very weight of national narratives in the curriculum and textbooks, and this conditions the content of the historical discourse that students can provide. As a result, no analysis of students' narrative productions can in any way be divorced from the "mediating" elements of the historical discourse.

\section{Methodology}

\subsection{Objectives}

The main aim of this research is to analyze the narrative abilities and the historical literacy of future elementary school teachers of history in Spain by means of a historical synthesis. This aim can be broken down into four more specific aims.

- $\quad$ To examine the complexity and coherence of students' narratives using solo taxonomy.

- To analyze the historical literacy of students through the historical meta-concepts in their narratives and the substantive or first-order content present in their accounts.

- To check the interrelationship between the complexity of students' narratives and their capacity to use historical meta-concepts and correctly articulate an account as a historical synthesis.

- To inquire into the presence of identity topics in students' narratives in relation to the history education they have received.

\subsection{Participants}

The study population comprised students of the degree in elementary school teaching at the Universities of Murcia and Valencia who were taking the last compulsory subject: Teaching of Social Sciences (tables I and II). The sample was of a probabilistic nature, since all members of the population had an equal likelihood of being chosen prior to sample selection (groups were randomly chosen). Sampling was nonstratified and 6 of the possible 14 groups were chosen (42\% of the total population).

Table I. Number of students participating in the research, per university

\begin{tabular}{l|c|c}
\hline University & Frequency & Percentage \\
\hline University of Murcia & 151 & 53.4 \\
University of Valencia & 132 & 46.6 \\
Total & 283 & 100 \\
\hline
\end{tabular}

Table II. Gender of students participating in the research

\begin{tabular}{l|c|c}
\hline Gender & Frequency & Percentage \\
\hline Female & 206 & 72.8 \\
Male & 77 & 27.2 \\
\hline
\end{tabular}

\subsection{Analysis and categorization tool}

Information was gathered through a written exercise in which the students were asked to write a historical narrative synthesis on the Christian conquest of lands under Muslim rule in the medieval Iberian Peninsula. These master narratives are a suitable tool for assessing students' historical meta-concepts and analyzing their representation of the past (Sáiz \& Gómez, 2016). Writing a historical synthesis and, therefore, establishing inclusion and exclusion criteria about the past in their accounts, allows students to appreciate what Chartier (2007, p. 22) defined as "the gap that exists between the past and its representation, between what was and what no longer is, and the narrative constructions that are put 
forward to occupy the place of that past". The historical content the task seeks - the Christian expansion over Muslim lands in the Middle Ages - is a key part of the historical narrative in the Spain of today (López, Carretero, \& Rodriguez 2015). In formal education the issue is addressed in elementary and throughout secondary education. At the informal level, it is also widely present, given its current importance in territorial, social, economic and political organization. Its essence is present in folklore and popular tradition, the greatest manifestation of which is in the "Moors and Christians" fiestas, but it is also present in mass communication media, through fictional recreations of history. It is precisely this huge presence in students' formal and non-formal education, together with the importance of this historical process on today's political map, that supports our choice of topic.

Two tools were used to analyze the information in the texts. Qualitative information was collected and analyzed in the Filemaker Pro database, which enabled us to determine the categories for analysis and the limits between them. Quantitative information was coded later using SPSS. Collection and analytical tools were validated by experts in teaching social sciences.

Different levels of complexity were established for the categories chosen, for systematic analysis of the main variables. Next, we examined the presence and level of second-order content or historical metaconcepts in the accounts. We used four of the categories from the classification by Seixas and Morton (2013), which allows different levels of progress in learning to be established (none, low, medium, and high). The definition criteria for the levels were adapted from the proposal by Seixas and Morton (2013) and Mora (2012). The first historical meta-concept analyzed was historical relevance, which values the importance attributed to a historical phenomenon. Second was cause and consequence. This concept involves the capacity to explain a historical phenomenon through the complex network of multiple causes and consequences it is based on. Third was change and continuity, which refers to describing changes by making an appropriate use of timing. The last concept was ethical dimension or historical awareness, which is the capacity to make judgments of explicit or implicit ethical value about the phenomenon.

A pilot empirical analysis for the presence and level of complexity of the historical thinking markers led to four levels being coded: level 0 , or none, which reflects a total absence of second-order concepts and scarce substantive and/or glaring historical errors; level 1 or basic, which shows that accounts were limited to describing minimum historical information presented linearly or accounts that included at least one historical thinking marker, although at low levels; level 2, or medium, which corresponded to accounts that included at least two markers, one at a medium level and the other at a medium or low level; and finally, level 3, which was awarded to accounts with high historical thinking and which included one or more well-explained markers.

Four levels were fixed for the presence and complexity of substantive content. Level 0 was for accounts that had notable historical shortcomings, an absence of or serious errors in information, either because no data or irrelevant data were included. Level 1 corresponded to information of a merely descriptive type, with linear ordering and some events or facts correctly provided, albeit with some inconsistencies in time references; it is basically a case of selected political-territorial issues from the Muslim invasion of the Iberian Peninsula in 711 to the Christian retaking of Granada in 1492. Level 2 covered writing with the same basic accounts of political events, but which were combined with some social-economic and cultural information and even some appraisals of the Muslim legacy from that time. Level 3 was for accounts that provided a greater amount of information through the inclusion of well-structured political, social, economic and cultural content.

With respect to substantive historical content, we also determine their denomination or conceptualization according to the content included in the accounts, whether the historical classification "Reconquista" is used, or other terms instead ("conquest", "spread", "expulsion", etc.). Finally, we add, to the categorizations by historical content and procedure, a level of complexity for the narratives on the basis of the solo taxonomy and distinguish the respective categories: prestructural, unistructural, multistructural, relational, and extended abstract (Biggs \& Tangs, 2007). 


\subsection{Methods, techniques and analysis of results}

Given the nature of the subject and the data collection tool, we had to use a methodological design that combined various techniques and strategies known as non-experimental methods. The work is evaluative research that aims to diagnose the narrative skills and the historical literacy of future primary school teachers. Specifically, it lies within the mixed or holistic framework in that it takes into account qualitative and quantitative methodological perspectives that allow us to make proposals for improvement based on the systematic, rigorous, objective, credible, reliable and valid collection of information and evidence (Lukas \& Santiago, 2009). This approach combines the comprehensive transforming potential of qualitative research with the explanatory predictive value of quantitative research (Sabariego \& Bisquerra, 2012). The main research into history education, as addressed from this field of knowledge, also insists on the complementary nature of quantitative and qualitative approaches (Barca, 2005; Barton, 2005, 2012; Grant, 2001).

The research stemmed from an exploratory cross-sectional design, using a pilot group (15\% of the data collected), which was followed by a descriptive cross-sectional design. Quantitative analysis techniques were applied by coding categories that could be coded, and using the statistics package spss to carry out frequency, means, percentages, chi-square and contingency table analysis and analysis of the dependence between variables. This reveals the underlying structure in the subjects' accounts and verifies the various contrasts between the subject categories we considered to be of interest.

The holistic approach also incorporated the qualitative methodological perspective from the phenomenological viewpoint. This has to do with describing, comparing, explaining and understanding the study from the participants' (future elementary school teachers') perspective. Through the phenomenological study, we attempt to identify all the aspects linked to the problems of our research that seem relevant and significant in the perceptions, beliefs, feelings and actions of socio-educational actors. We follow a fundamentally inductive procedure, as recommended by Sandín (2003) and Sabariego, Massot and Dorio (2012).

Qualitative data was processed by analyzing students' narrative discourses and conceptual complexity, and using the subsequent coding codification for the markers mentioned above. Open coding has also been considered when determining the content of students' discourse and in order to determine the levels in some of the categories and concepts analyzed. Thus, we followed strategies derived from grounded theory (Strauss \& Corbin, 1991; Flick, 2007) that have been used in other research into history education (Barca, 2005).

\section{Results and Discussion}

The results confirm the low level of narrative skills and historical knowledge of students in the degree in elementary school teaching at the Universities of Murcia and Valencia. First, we should note the low level of substantive content, what students knew about the content requested, even though it came from their basic training and is informal knowledge. Second, there was an absence of skills in organizing an account, in how they narrated or presented the content, from the standpoint of solo taxonomy and in terms of the second-order or historical meta-concepts present.

Table III. Level of complexity of students' narratives (percentages)

\begin{tabular}{c|c|c|c}
\hline Level & $\begin{array}{c}\text { SOLO } \\
\text { Taxonomy }\end{array}$ & $\begin{array}{c}\text { Historical } \\
\text { Content }\end{array}$ & $\begin{array}{c}\text { Historical } \\
\text { metaconcepts }\end{array}$ \\
\hline 1 & 46.3 & 50.2 & 49.1 \\
2 & 42.3 & 37.7 & 42.0 \\
3 & 11.0 & 11.7 & 8.5 \\
4 & 0.4 & 0.4 & 0.4 \\
Total & 100.0 & 100.0 & 100.0 \\
\hline
\end{tabular}

Historical content and historical metaconcepts ( $1=$ null; $2=$ basic; $3=$ medium; 4=high). solo Taxonomy (1=Pre-structural; 2= Monostructural; 3=Multi-structural; 4=Relational). 
Half of the students offered no noteworthy information and a similar percentage showed minimum communication skills; $46 \%$ of students were unable to articulate their account acceptably when the sOLO taxonomy was applied (table III). Apart from spelling and grammatical errors, the most outstanding feature of the accounts was their disjointedness. A large number did not meet the minimum requirements expected of higher education training for students to become elementary school teachers. Similarly, 50\% of the narratives were seriously deficient in substantive historical content. Some students claimed the Muslims entered the Iberian Peninsula from the north (through France) and even spoke of the Christian kingdoms as outside entities. Several set the events in some pre-Christ period, while others had them occurring much later than they did. Also indicative was the fact that many of the accounts claimed that the Muslims had ousted the Romans from the Iberian Peninsula, when they actually arrived almost 250 years after the fall of the western Roman Empire.

Approximately $40 \%$ of narratives did meet the minimum levels of communication expected of higher education students, although these were mostly linear, descriptive, and one-dimensional accounts. They dated the Muslim invasion (711) and their final expulsion (1492) correctly, and the accounts included names of considerable importance. Yet they lacked control of second-order concepts; the historical phenomena included were limited to basic political-territorial facts, which were at times very fragmented with wayward time references. The events and figures most referred to were "Pelayo", the "Battle of Covadonga", "El Cid", the "Catholic Monarchs" and the fall of Granada in 1492. In Valencia there were also allusions to James I (Jaime I).

When analyzing historical thinking capacities, we found that just $9 \%$ of students showed any consistent mastery of one or more second-order concepts, i.e. an average to high level. Indeed, $70 \%$ of accounts did not include markers showing the importance of the historical process at even a low level. Most students narrated the process disjointedly in terms of its social and economic reality or with respect to today's territories. The most frequent interconnection is the Arab cultural and artistic legacy (monuments, mosques, etc.), although it is anecdotic. Furthermore, $85 \%$ made no reference to causes and consequences, to the motivations that led to the advance of the Christian kingdoms in the Muslim territory, or to the different paces of the process. Many of the reasons outlined are lacking in historical thinking skills. For example, some students wrote that the Christians "decided one day that they had to reconquer the Iberian Peninsula, and they did so quickly", a crass simplification of an 800-year process that left a footprint that is still very present in the Spain of today. Likewise, $86 \%$ of narratives did not develop arguments about the changes and continuities associated with the process, while $96 \%$ included no marker associated with the concept of historical awareness or the ethical dimension of history; these students' work showed no value judgments connecting past events to current social, economic, political or cultural configurations. Furthermore, students that did use these historical meta-concepts did so, for the most part, at a very low level.

Contingency tables were used in spss to test variable interaction and reveal significant results. First, the complexity of the accounts and the presence of historical thinking markers increase proportionally to an increase in substantive content. This would point to a close association between the two variables and to a need for a teaching that combines historical content with historical thinking competencies, but without ever losing sight of the interrelations between them (Lee, 2005). To continue to put forward dichotomies between content and competencies when teaching history is reductionist and counterproductive (Cain \& Chapman, 2014).

Second, students who displayed the most historical information (in first and second-order concepts) showed greater organizational capacity according to the solo taxonomy. This is seen in tables IV, V and $\mathrm{VI}$, which show a contingency table, the Pearson chi-square and the Kendall Tau-b in order to verify the hypothesis of independence between the variables (level of historical thinking in the narratives and the level of complexity in the accounts) and the degree of dependence between them. The chi-square value (487.475, with a bilateral asymptotic significance of .000) implies that the variables "historical thinking" and "solo typology" are dependent. The presence of second-order historical content is conditioned by the complexity of the narrative. Dependence between variables, according to the Kendall Tau-b, reached .906 , confirming a strong dependence. 
Table IV. Contingency table Historical Thinking Complexity * SOLO Typology

\begin{tabular}{l|l|c|c|c|c|c}
\cline { 3 - 6 } \multicolumn{2}{c}{} & \multicolumn{4}{c|}{ SOLO TYPOLOGY } & \multirow{2}{*}{} \\
\cline { 2 - 6 } \multicolumn{2}{c}{} & Prestructural & Monostructural & Multistructural & Relational & Total \\
\hline $\begin{array}{l}\text { Historical } \\
\text { Thinking } \\
\text { Complexityy }\end{array}$ & $\begin{array}{l}\text { Pre-structural with } \\
\text { historical errors }\end{array}$ & 131 & 3 & 5 & 0 & 139 \\
& $\begin{array}{l}\text { Basic linear structural } \\
\text { Medium historical } \\
\text { thinking }\end{array}$ & 0 & 117 & 1 & 1 & 119 \\
& High historical thinking & 0 & 0 & 24 & 0 & 24 \\
\hline Total & 131 & 120 & 31 & 1 & 283 \\
\hline
\end{tabular}

Table V. Chi-square tests

\begin{tabular}{l|c|c|c}
\cline { 2 - 4 } & Value & d.f. & $\begin{array}{c}\text { Asymptotic sig. } \\
\text { (bilateral) }\end{array}$ \\
\hline Pearson chi-square & $487.475 a$ & 9 & .000 \\
Likelihood ratio & 461.237 & 9 & .000 \\
Linear by linear association & 223.195 & 1 & .000 \\
N valid cases & 283 & & \\
\hline
\end{tabular}

Table VI. Symmetric measures

\begin{tabular}{l|c|c|c|c}
\cline { 3 - 5 } & Value & $\begin{array}{c}\text { Asymp type } \\
\text { error }^{\mathrm{a}}\end{array}$ & $\begin{array}{c}\mathrm{T} \\
\text { approximate }^{\mathrm{b}}\end{array}$ & $\begin{array}{c}\text { Sig. } \\
\text { approximate }^{\prime}\end{array}$ \\
\hline Ordinal by ordinal Kendall Tau-b & .909 & .030 & 26.265 & .000 \\
\cline { 1 - 5 } $\mathrm{N}$ valid cases & 283 & & & \\
\hline
\end{tabular}

a. Assuming the alternative hypothesis.

b. Using a typical asymptotic error based on the null hypothesis.

The scarce skills shown by students in organizing historical discourse is due to the design of the syllabus for the degree in elementary school teaching in Spain, and an irregular and insufficient history education at lower levels. There is still a predominance of history teaching based on memorizing and reproducing factual and conceptual content, as is borne out in elementary and secondary school examinations (Gómez \& Miralles, 2013; Sáiz \& Fuster, 2014). Furthermore, incorporation of basic educational competencies is not remedying this deficiency, which is the fruit of school routine arising from a treatment of history in curricula that has been repeated and maintained in textbooks and teaching practices (Gómez, 2014; Sáiz, 2011 and 2013).

Both Wineburg (2001) and VanSledright (2011) have pointed out the dangers besetting a linear teaching of history, based on the building of a nation, that seeks to compete with a mass consumption culture. An approach to historical content that seeks to consolidate a collective memory of a nation inculcates a passive role in students. Besides, as VanSledright (2011) points out, this converts the teacher into a narrator of the nation's deeds, with an emphasis on its most emotional aspects, and aims, in the long run, to capture the attention of a student accustomed to audiovisual consumption. This has several dangers: the low cognitive level demanded by this type of teaching, and students' reluctance to understanding, from multicultural contexts, history that has been already written from a specific perspective.

The results from the analysis of the narratives are a direct consequence of the hegemony of this descriptive historical discourse, which treats historical time one-dimensionally and is based on the building of a nation and the reproduction of the master narratives. This causes an epistemological conception of history as closed knowledge. There is a dominance, in the teaching of this subject, of an approach based on a linear account of past facts that have been selected by the official curriculum, the 
textbook, the center's programme, and finally, the teacher. Here we should remember the concept of narrative mediation and the narrative schematic template (Wertsch, 2002). The general structures of these master narratives, as is the case with the historical synthesis requested herein (the Christian expansion over Islam in the medieval Iberian Peninsula), changes very little over the years. Moreover, these national narratives often weigh heavily in both formal and informal education (Sáiz, 2015), hence their huge influence on how students interpret historical phenomena (VanSledright, 2008). Indeed, some of the results of the study bear this out. In recent decades the most significant change in the structure of the national narrative is that textbooks have incorporated more information on the Muslim cultural and artistic legacy (the Mosque of Cordoba, the Alhambra in Granada...) and an idyllic vision of coexistence between cultures (Sáiz, 2012). This has been confirmed in students' accounts, with almost 30\% making reference to this issue.

Neither is it surprising that almost $65 \%$ of the students referred to the process as the "Reconquista", or reconquest (table VII). Those using this term also produced accounts of greater narrative complexity and with more substantive content. In other words, the lack of references to the process as the "Reconquista" was not due, in most of the accounts, to doubt over its historiographical validity, but because students probably did not situate the historical process correctly. It is true that the term "Reconquista" continues to provoke academic controversies historically and in the teaching of history. Its detractors claim that it is a historiographical construction that seeks legitimacy as a national narrative (López et al., 2015; Ríos, 2011; Sáiz, 2012 and 2015). Others, however, accept the inexactness of the term but hold the opinion that it remains an operative one for defining a key process in the Iberian Peninsula in medieval times (García-Fitz, 2010). In any case, the weight of this denomination when narrating the historical process in both textbooks and in student assessment shows the pervasiveness of a traditional and very classical vision of the historical phenomenon. Much research confirms the use of the term "Reconquista" and events and characters involved in the process. The denomination enjoys a hegemony in secondary education history manuals (Sáiz, 2012), and examinations and manuals in elementary education continue to feature mythical names such as "Pelayo", who is presented to students as a real historical person, despite his scant presence in primary sources. The knowledge imparted, on the other hand, is practically reduced to accounts of the beginnings of the Christian conquest and the similarly disputed Battle of Covadonga (Gómez, Rodríguez \& Miralles, 2015). The Catholic Monarchs appear as the great unifiers of what will become the Spanish nation, with the climax being the fall of Granada and the end of Arab rule in the Iberian Peninsula in 1492. Again, these narrative mediators - the textbooks and student assessment have an impact on the direction taken by the students' accounts.

Table VII. Terms used by students to refer to the process

\begin{tabular}{l|c|c}
\hline & Frequency & Percentage \\
\hline Reconquest & 182 & 64.3 \\
Conquest & 58 & 20.5 \\
Expulsion & 14 & 4.9 \\
Co-existence & 6 & 2.1 \\
None & 23 & 8.1 \\
Total & 283 & 100 \\
\hline
\end{tabular}

\section{Conclusion}

With respect to the aims of this study, the results show that future elementary school teachers have not received an appropriate history education in substantive content or historical thinking competencies. Moreover, their accounts reproduce the identity topics set out in the textbooks and which are required of them in the examinations. It is difficult, therefore, for them to meet the minimum subject and teaching levels required, at least with regard to the standards that today's research into the didactics of social sciences and history education deems acceptable (Wineburg, 2001; Barton \& Levstik, 2004; VanSledright, 
2014). In these circumstances there is a need for a transversal intervention to increase the presence of history education (in both substantive content and historical competencies, which are closely related) in basic levels of education (elementary and secondary), as a complement to future teachers' training.

The students' accounts reflect the dominance of a national narrative that presents itself as a closed, unquestioned issue. There is an insistence on the achievements of a nation of classical origins (with a particular influence from Romanization), which was enriched through mixing with other cultures, and then reaffirmed itself by driving out the Muslims before gaining fame as the discoverer of new lands and finally becoming an exemplary democracy. The historical downturns and discontinuities are glossed over or played down. One of the main reasons is to be found in the curriculum, which is encyclopedic and culturalist. Textbooks and examinations are the fruit of a legislation that, in Spain, is under continuous change, but which in the sphere of school narrative history shows more continuities than changes. Textbooks and examinations in basic education, as narrative mediators, leave their traces in the accounts analyzed in this study. The persistence of these identity topics stretches beyond compulsory education. The fact that it still persists in future teachers is a serious problem, as the likelihood is that these will pass it on to their future pupils.

\section{References}

Ashby, R. (2004). Developing a concept of historical evidence: Students' ideas about testing singular factual claims. International Journal of Historical Learning, Teaching and Research, 4(2).

Bage, G. (1999). Narrative matters. Teaching and learning history through story. New York: Routledge.

Barca, I. (2000). O pensamento histórico dos jovens. Braga: Universidade do Minho.

Barca, I. (2005). "Till new facts are discovered": Students' ideas about objectivity in history. In R. Ashby, P. Gordon, \& P. Lee (Eds.), International review of history education, Vol. 4: Understanding history: Recent research in history education (pp. 68-82). New York: RoutledgeFalmer.

Barton, K. C. (2005). "Best not to forget them": Adolescents' judgments of historical significance in Northern Ireland. Theory and Research in Social Education, 33, 9-44.

Barton, K. C. (2012). Applied research: Educational research as a way of seeing. In A. McCully, G. Mills, \& C. van Boxtel (Eds.), The professional teaching of history: UK and Dutch perspectives (pp. 1-15). Coleraine, Northern Ireland: History Teacher Education Network.

Barton, K., \& Levstik, L. (2004). Teaching history for the common good. New Jersey: Lawrence Erlbaum.

Biggs, J., \& Tang, C. (2007). Teaching for quality learning at university. What the student does. Berkshire: McGrawHill.

Bruner, J. (1986). Actual minds. Possible worlds. Cambridge, MA: Harvard University Press.

Bruner, J. (1990). Acts of meaning. Cambridge, MA: Harvard University Press.

Bruner, J. (1997). La educación puerta de la cultura [Education, a door to culture]. Madrid: Visor.

Cain, T., \& Chapman, A. (2014). Dysfunctional dichotomies? Deflating bipolar constructions of curriculum and pedagogy through case studies from music and history. The Curriculum Journal, 25(1), 111-114.

Carretero, M., \& López, C. (2009). Estudios cognitivos sobre el conocimiento histórico: aportaciones para la enseñanza y la alfabetización histórica [Cognitive studies on historical knowledge: contributions to 
historical literacy and teaching]. Enseñanza de las Ciencias Sociales, 9, 79-83.

Carretero, M., \& Van Alphen, F. (2014). Do master narratives change among high school students? A characterization of how national history is represented. Cognition and Instruction, 32(3), 290-312, doi:10.1080/07370008.2014.919298

Carretero, M., \& Atorresi, A. (2008). Pensamiento narrativo [Narrative thinking]. In M. Carretero \& M. Asensio (Eds.), Psicología del pensamiento [Psychology of thought] (pp. 269-289). Madrid: Alianza.

Carretero, M., \& Bermúdez, A. (2012). Constructing histories. In J. Valsiner (Ed.), Oxford Handbook of Culture and Psychology (pp. 625-646). Oxford University Press.

Carretero, M., \& López, C. (2010). The narrative mediation on historical remembering. In S. Salvatore, J. Valsiner, J. T. Simon \& A. Gennaro (Eds.), Yearbook of Idiographic Science (Vol. 3) (pp. 285-294). Rome: Firera \& Liuzzo.

Carretero, M., López, C., Fernanda, M. F., \& Rodríguez-Moneo, M. (2012). Students' historical narratives and concepts about the nation. In M. Carretero, M. Asensio \& M. Rodríguez-Moneo (Eds.), History education and the construction of national identities (pp. 153-170). Charlotte, cT: Information Age Publishing.

Carretero, M., \& Voss, J. (Comp.) (2004). Aprender y pensar la historia. [Learn and think History]. Buenos Aires: Amorrortu.

Chapman, A. (2011). Understanding historical knowing: Evidence and accounts. In L. Perikleous \& D. Shemilt (Eds.), The future of the past: Why history education matters (pp. 169-216). Nicosia: Association for Historical Dialogue and Research, Kailas Printers.

Chartier, C. (2007). La historia o la lectura del tiempo [The history or reading of time]. Madrid: Gedisa.

Clark, P. (Ed.) (2011). New possibilities for the past. Shaping history education in Canada. VancouverToronto: UBC Press.

Cooper, H., \& Chapman, A. (Ed.) (2009). Constructing history. London: Sage.

Flick, U. (2007). Introducción a la investigación cualitativa [Introduction to qualitative research]. Madrid: Morata.

García-Fitz, F. (2010). La Reconquista [The reconquest]. Universidad de Granada.

Gómez, C. J. (2014). Pensamiento histórico y contenidos disciplinares en los libros de texto. Un análisis exploratorio de la Edad Moderna en 2. ${ }^{\circ}$ de la ESO [Historical thought and disciplinary content in textbooks. An exploratory analysis of the modern era in the 2 nd year of secondary education]. Ensayos. Revista de la Facultad de Educación de Albacete, 29(1), 131-158.

Gómez, C. J., \& Miralles, P. (2013). Los contenidos de ciencias sociales y las capacidades cognitivas en los exámenes de tercer ciclo de educación primaria ¿Una evaluación de competencias? [The content of social sciences and cognitive ability in exams in the third cycle of primary education, an assessment of skills?] Revista Complutense de Educación, 24(1), 91-121.

Gómez, C. J., \& Miralles, P. (2015). ¿Pensar históricamente o memorizar el pasado? La evaluación de los contenidos históricos en la educación obligatoria en España [Think historically or memorize the past? Assessment of historical content in obligatory education in Spain]. Revista de Estudios Sociales, 52, 52-68.

Gómez, C. J., Ortuño, J., \& Molina, S. (2014). Aprender a pensar históricamente. Retos para la historia en el 
siglo XXI [Learning to think historically. Challenges for history in the 21st century]. Tempo e Argumento, 6(11), $1-25$.

Gómez, C. J., Rodríguez, R. A., \& Miralles, P. (2015). La enseñanza de la Historia en Educación Primaria y la construcción de una narrativa nacional. Un estudio sobre exámenes y libros de texto en España [Teaching history in primary education and the construction of a national narrative. A study of exams and textbooks in Spain]. Perfiles Educativos, XXXVII (150), 20-38.

Grant, S. G. (2001). It's just the facts, or is it? The relationship between teachers' practices and students' understandings of history. Theory and Research in Social Education, 29, 65-108.

Henríquez, R. (2004). Relatando el pasado. El uso de las narraciones en la didáctica de las ciencias sociales [Narrating the past. The use of narration in teaching social sciences], in Batllori, R., Gómez, E., Oller, M., \& Pagès, J. (Eds.). De la teoria al aula. Formació del professorat i ensenyament de les Ciències Socials (pp. 238248). Barcelona, Departament de Didàctica de la Llengua, de la Literatura i de les Ciències Socials.

Lee, P. (2001). History in an information culture. International Journal of Historical Learning. Teaching and Research, 1(2).

Lee, P. (2005), Putting principles intro practice: Understanding history. In M. Donovan \& J. Bransford (Ed.), How students learn: History in the classroom (pp. 31-77). Washington: National Academies Press.

Lee, P. (2011). History education and historical literacy. In I. Davies (Ed). Debates in History Teaching (6372). London-New York: Routledge.

Lee, P., \& Ashby, R. (2000). Progression in historical understanding among students ages 7-14. In P. N. Stearns, P. Seixas \& S. Wineburg (Ed.), Knowing, teaching and learning history. National and international perspectives (199-222), New York-London: New York University Press.

Lee, P., Ashby, R., \& Dickinson, A. (2004). Las ideas de los niños sobre la historia [Children's ideas about history]. In M. Carretero \& J. Voss (Comp.), Aprender y pensar la historia (pp. 217-248). Buenos Aires: Amorrortu.

Lee, P., \& Shelmilt, D. (2004). I just wish we could go back in the past and find out what really happened: progression in understanding about historical accounts. Teaching History, 117, 25-31.

Lévesque, S. (2008). Thinking historically. Educating students for the 21th century. University of Toronto Press.

López, C., Carretero, M., \& Rodríguez-Moneo, M. (2015). Conquest or reconquest? Students' conceptions of nation embedded in a historical narrative. Journal of the Learning Sciences, 24, 252-285. doi:10.1080/10508406.2014.919863

Lukas, J. F., \& Santiago, K. (2009). Evaluación educativa [Educational assessment]. Madrid: Alianza Editorial.

McAdams, D. P. (2006). The role of narrative in personality psychology today. Narrative Inquiry, 16(1), 1118.

Monte-Sano, Ch. (2010). Disciplinary literacy in history: An exploration of the historical nature of adolescents' writing. The Journal of the Learning Sciences, 19(4), 539-568.

Mora, G., \& Paz, R. (2012). El modelo de educación histórica. Experiencia de innovación en la educación básica de México [The history education model. The experience of an innovation in basic-level education in Mexico], Enseñanza de las Ciencias Sociales, 11, 87-98. 
Peck, C., \& Seixas, P. (2008). Benchmarks of historical thinking: First steps. Canadian Journal of Education, 31(4), 1015-1038.

Prats, J. (2002). Hacia una definición de la investigación en Didáctica de las Ciencias Sociales [Towards a definition of research in the didactics of social science]. Enseñanza de las Ciencias Sociales. Revista de investigación, 1, 81-89.

Ricoeur, P. (1995). Tiempo y narración [Time and narrative]. Madrid: Cristiandad.

Ríos, M. (2011). La Reconquista. Una construcción historiográfica (siglos XVI-XIX) [The reconquest. A historiographic construction]. Madrid: Marcial Pons.

Rüsen, J. (2005). History: Narration, interpretation, orientation. New York: Berghahn.

Rüsen, J. (2010). E o ensino de História. Curitiba: Editora UfPR.

Sabariego, M., \& Bisquerra, R. (2012). El proceso de investigación (parte I) [The research process (part I)]. In R. Bisquerra (Coord.), Metodología de la investigación educativa [Methodology of educational research] (pp. 89-125). Madrid: La Muralla.

Sabariego, M., Massot, I., \& Dorio, I. (2012). Métodos de investigación cualitativa [Qualitative research methods]. In R. Bisquerra (Coord.), Metodología de la investigación educativa [Methodology of educational research] (pp. 293-328). Madrid: La Muralla.

Sáiz, J. (2011). Actividades de libros de texto de Historia, competencias básicas y destrezas cognitivas, una difícil relación: análisis de manuales de $1 .{ }^{\circ}$ y $2 .^{\circ}$ de ESO [History textbook activities and basic and cognitive skills, a difficult relationship: analysis of textbooks from 1st and 2nd grade of secondary education]. Didáctica de las Ciencias Experimentales y Sociales, 25, 37-64.

Sáiz, J. (2012). La Península Ibérica medieval y las identidades en los actuales libros de texto de historia de 2. ${ }^{\circ}$ de ESO [The medieval Iberian península and identities in today's textbooks. Íber. Didáctica de las Ciencias Sociales, Geografía e Historia, 70, 67-77.

Sáiz, J. (2013). Alfabetización histórica y competencias básicas en libros de texto de historia y en aprendizaje de los estudiantes [Historical literacy and basic skills in history textbooks and students' learning]. Didáctica de las Ciencias Experimentales y Sociales, 27, 43-66.

Sáiz, J. (2015). Educación histórica y narrativa nacional [Historical education and national narrative]. Tesis Doctoral. Universidad de Valencia, España.

Sáiz, J., \& Fuster, C. (2014). Memorizar historia sin aprender pensamiento histórico. Las PAu de Historia de España [Memorizing history without learning historical thinking. University access tests in history in Spain]. Investigación en la Escuela, 84, 46-57.

Sáiz, J., \& López Facal, R. (2015). Competencias y narrativas históricas: el pensamiento histórico de estudiantes y futuros profesores españoles de Educación Secundaria [Historical competencies and narratives: the historical thinking of students and pre-service teachers]. Revista de Estudios Sociales, 52, 87-101.

Sáiz, J., \& Gómez, C.J. (2016). Investigar el pensamiento histórico y narrativo en la formación del profesorado: fundamentos teóricos y metodológicos [Researching historical and narrative thinking in teacher education: theoretical and methodological basis]. Revista Electrónica Interuniversitaria de Formación del Profesorado, 19(1), 175-190.

Sandín, M. P. (2003). Investigación cualitativa en la educación: Fundamentos y tradiciones [Qualitative 
research in education: Foundations and traditions]. Madrid: McGraw-Hill/Interamericana de España. 
Schmidt, M. A., \& Barca, I. (Org.). (2009). Aprender história: perspectivas da educação histórica. Brasil: Unijui.

Seixas, P., \& Morton, T. (2013). The big six historical thinking concepts. Toronto: Nelson.

Stearns, P. N., Seixas, P., \& Wineburg, S. (Eds.) (2000). Knowing, teaching and learning history. National and international perspectives. New York-London: New York University Press.

Strauss, A., \& Corbin, J. (1991). Basics of qualitative research - Grounded theory procedures and techniques. Newbury Park, CA: Sage.

Topolsky, J. (2004). La estructura de las narrativas históricas y la enseñanza de la historia [The structure of historical narratives and history teaching]. In M. Carretero \& J. Voss (Comps.), Aprender y pensar la historia [Learning and thinking about history] (pp. 101-120). Buenos Aires: Amorrortu.

Van Drie, J., \& Van Boxtel, C. (2008). Historical reasoning: towards a framework for analyzing students' reasoning about the past. Educational Psychology Review, 20, 87-110.

VanSledright, B. A. (2008). Narratives of nation-state, historical knowledge and school history education. Review of Research in Education, 32(1), 109-146.

VanSledright, B. A. (2011). The challenge of rethinking history education. On practice, theories, and policy. New York: Routledge.

VanSledright, B. A. (2014). Assessing historical thinking and understanding. Innovation design for new standards. New York: Routledge.

Wertsch, J. V. (2002). Voices of collective remembering. Cambridge University Press.

Wineburg, S. (2001). Historical thinking and other unnatural acts: Charting the future of teaching the past. Philadelphia: Temple University Press.

Wineburg, S. Martin, D., \& Montesano, Ch. (2013). Reading like a historian. Teaching literacy in middle \& high school history classrooms. New York: Teachers. 